\title{
ATTRIBUTES OF ACIDITY AND EXCHANGEABLE CATIONS IN OXISOL FERTILIZED BY PHOSPHATE ALKALINE BIOSOLID \\ ATRIBUTOS DE ACIDEZ E CÁTIONS TROCÁVEIS EM LATOSSOLO FERTILIZADO POR BIOSSÓLIDO ALCALINIZADO FOSFATADO
}

\author{
Luiz Carlos DA SILVA ${ }^{1}$ \\ Luiz Antonio Corrêa LUCCHESI ${ }^{2}$ \\ Henrique Soares KOEHLER ${ }^{3}$
}

\begin{abstract}
Alkaline biosolid enriched by phosphorus $(P)$ increase soil extractable $P$ more than applied alone. It also can exert further effects above soil acidity attributes and exchangeable calcium and magnesium. These facts can contribute to the solution of problems with final destination, attracting farmers to use of adequate quantities of these biosolids by reducing his costs with $\mathrm{P}$ fertilization and liming operations. The objective of this work was to evaluate the acidity attributes $\mathrm{pH}\left(\mathrm{CaCl}_{2} 0.01\right.$ mol dm${ }^{-3}$ ), exchangeable aluminum, potential acidity and exchangeable calcium and magnesium on an acidic Oxisol fertilized with alkaline biosolid phosphated with different levels of phosphorus from three sources after common bean grown under greenhouse condition. An alkaline biosolid was phosphate with $0 \% \mathrm{P}, 0.436 \% \mathrm{P}, 0.872 \% \mathrm{P}$ and $1.745 \% \mathrm{P}$ from partially acidulated rock phosphate Alvorada, single superphosphate and triple superphosphate. To stablish the treatments was recommended $45.85 \mathrm{~kg} \mathrm{P}^{-1}$ of $\mathrm{P}$ from the levels of $\mathrm{P}$ added, except from $0 \% \mathrm{P}$. Four levels and 3 sources of $\mathrm{P}$ generated 12 treatments with 4 replications. Treatments were applied to $2.5 \mathrm{~kg}$ dry weight of Oxisol from Arapoti, PR, Brazil, in vases, which was cultivated with 6 common bean plants (cV. IPR Uirapuru). Under these experimental conditions phosphate alkaline biosolid applied in acidic Oxisol provided the largest increases of soil $\mathrm{pH}$, exchangeable calcium and magnesium and decreases in exchangeable aluminum and potential acidity with the level of $0.436 \% \mathrm{P}$ from the partially acidulated rock phosphate Alvorada and single superphosphate.
\end{abstract}

Key words: soil pH; potential acidity; exchangeable aluminum; Phaseolus vulgaris

\section{RESUMO}

Biossólido alcalinizado enriquecido com fósforo $(P)$ aumenta o $P$ extraível mais do que aplicado sozinho. Também pode exercer efeitos adicionais sobre os atributos de acidez e cálcio e magnésio trocáveis do solo. Estes fatos podem contribuir para solução de problemas de destinação final, atraindo produtores à utilização de quantidades adequadas destes biossólidos por reduzir seus custos com adubação e correção de solos. O objetivo deste trabalho foi avaliar os atributos de acidez $\mathrm{pH}\left(\mathrm{CaCl}_{2} 0,01 \mathrm{~mol} \mathrm{dm}^{-3}\right)$, alumínio trocável, acidez potencial e cálcio e magnésio trocáveis em Latossolo fertilizado com biossólido de esgoto alcalinizado fosfatado com diferentes níveis de fósforo de três fontes após o cultivo de feijoeiro comum em casa de vegetação. Um biossólido alcalinizado foi fosfatado com $0 \% \mathrm{P}, 0,436 \% \mathrm{P}, 0,872 \% \mathrm{P}$ e $1,745 \% \mathrm{P}$ de fosfato natural parcialmente acidulado Alvorada, superfosfato simples e superfosfato triplo. Para estabelecer os tratamentos recomendou-se $45,85 \mathrm{~kg} \mathrm{ha}^{-1}$ de $\mathrm{P}$ a partir dos níveis de $\mathrm{P}$ adicionado, exceto do nível $0 \% \mathrm{P}$. Quatro níveis e 3 fontes de $\mathrm{P}$ adicionado geraram 12 tratamentos com 4 repetições. Os tratamentos foram aplicados a $2,5 \mathrm{~kg}$ de Latossolo Vermelho Distrófico típico, ácido, em vasos cultivados com 6 plantas de feijoeiro (cv. IPR Uirapuru). Sob estas condições experimentais biossólido de esgoto alcalinizado fosfatado proporcionou os maiores aumentos de $\mathrm{pH}$ do solo e cálcio e magnésio trocáveis e diminuições do alumínio trocável e acidez potencial com o nível de $0.436 \% \mathrm{P}$ de fosfato natural parcialmente acidulado Alvorada e superfosfato simples.

Palavras-chave: $\mathrm{pH}$ do solo; acidez potencial; alumínio trocável; Phaseolus vulgaris

\footnotetext{
${ }^{(1)}$ Agronomist Ms, Scholarship of CAPES, Federal University of Amazon State, Campus Vale do Rio Madeira, Education, Agriculture and Environment Institute. Rua 29 de Agosto, 786, bairro: Centro, Humaitá-AM, CEP:69800-000. E-mail: luiz_silva03@yahoo.com.br.

${ }^{(2)}$ Federal University of Parana State (UFPR), Division of Agricultural Sciences, Rua dos Funcionários, 1540, Juvevê, CEP 80035-050, Curitiba, PR. E-mail: Iclucche@ufpr.br

(3) Federal University of Parana State (UFPR), Division of Agricultural Sciences, Rua dos Funcionários, 1540, Juvevê, CEP 80035-050, Curitiba, PR. E-mail: koehler@agrarias.ufpr.br
} 
DA SILVA L.C. et al. Attributes of acidity and exchangeable...

\section{INTRODUCTION}

The applicaton of sewage alkaline biosolids to agricultural soils can constitute a new sustainable method to eliminate this residues from the urban environment. These alkaline biosolids have in its composition organic matter and macro and micronutrients besides alkaline reaction in soils (Logan e Harrison, 1995). Its alkaline reaction is due to the presence of alkaline materials as calcium and magnesium carbonates $\left(\mathrm{CaCO}_{3}, \mathrm{MgCO}_{3}\right)$ and calcium oxide and hidroxide $\left(\mathrm{CaO}, \mathrm{Ca}(\mathrm{OH})_{2}\right)$ used in the treatment process (N-Viro Process or single lime and limekiln materials addition). Therefore, to the effect of increasing in the Mehlich-1 soil phosphorus (P) concentration observed by Da Silva et al. (2010), can be added the increasing in the soil $\mathrm{pH}$ (Silva et al., 2001; Silva et al., 1998; Sloan e Basta, (1995) and the consequent precipitation of exchangeable aluminum $\left(\mathrm{Al}^{3+}\right)$ from the soil solution on a non-toxic form and the reduction of the soil acidic potential (Guedes et al., 2006). Increases in exchangeable calcium $\left(\mathrm{Ca}^{2+}\right)$ and magnesium $\left(\mathrm{Mg}^{2+}\right)$ (Silva et al., 2001 ) in soils also have been verified when sewage alkaline biosolids are applied to the soil due to the high total content of these elements when these materials are treated by the alkaline processes ( $\mathrm{Da}$ Silva et al., 2010).

The main sources of phosphorus $(P)$ used in agricultural systems are single superphosphate and triple superphosphate which have a high calcium concentration in its composition. Single superphosphate is also a sulphur (S) source which occurs in the form of dihidrated calcium sulphate (gypsum). Partially acidulated rock phosphate are considered alternative sources of phosphorus and also have high calcium concentration in its composition according to Novais e Smith (1999). The existence of a high degree of phosphate substitution $\left(\mathrm{PO}_{4}{ }^{3-}\right)$ by carbonate $\left(\mathrm{CO}_{3}{ }^{2-}\right)$ (high quotient carbonate/ phosphate) generate instability into the crystal of the rock phosphate which constitute its non-acidulated portion. For that reason they are more reactive in soils (Korndörfer et al., 1999) and exert further positive effects in the soil acidity attributes and exchangeable calcium and magnesium. Beltrán et al. (1998) applied equal agronomic doses of phosphorus from the reactive Alvorada phosphate rock in the soil, single superphosphate and triple superphosphate. They verified that the soil $\mathrm{pH}$ was increased for all phosphorus sources. The increase was more accentuated when the reactive rock phosphate was applied. Vieira et al. (2005) observed increases in the soil $\mathrm{pH}$ when they applied an agronomic dose of triple superphosphate. Osztoics et al. (2005) refute these results when they measure the $\mathrm{pH}$ of a soil treated with single superphosphate. These same authors verified that the soil $\mathrm{pH}$ increases concomitantly the increasing doses of a reactive Algeria rock phosphate. This fact was attributed to its high quo- tient of carbonate/phosphate (Novais e Smith, 1999) that gives to this rock phosphate a larger reactivity in comparison to the superphosphates.

High quantities of sewage alkaline biosolids have been applied to the soils to supply the cropexigencies by nutrients as nitrogen and phosphorus. This fact can increase soil $\mathrm{pH}$ to an exceeding level and generate a prejudicial environment to the plant growth. Phosphorus addition to sewage biosolids from alternative and, or traditional phosphorus sources can be a sustainable practice from the economic and environmental point of view since less quantities of biosolids are incorporated in soils. The lime potential of these alkaline biosolids and of the $P$ sources added can stimulate and attract the farmers to the use of adequate quantities of these biosolids. Additionally, it can reduce the costs with operations related to the liming and phosphate fertilization of the common bean farmers in Parana State, Brazil, who in general, have a familiar and non-capitalized character.

The objective of this work was to evaluate the acidity attributes $\mathrm{pH}\left(\mathrm{CaCl}_{2} 0.01 \mathrm{~mol} \mathrm{dm}^{-3}\right)$, exchangeable aluminum, potential acidity and exchangeable calcium and magnesium on an acidic Oxisol fertilized by alkaline biosolid phosphated with different levels of phosphorus from three sources after common bean grown under greenhouse condition.

\section{MATERIAL AND METHODS}

The experiment was carried out in the greenhouse of the Soil and Agricultural Engineering Department of the Federal University of Parana

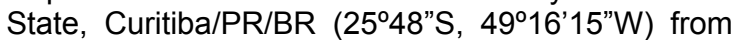
July to November, 2006.

The arable layer of a silt loam acidic Oxisol (LVDt) from Arapoti, Parana State, Brazil, was sieved on a $2 \mathrm{~mm}$ sieve. All the soil analysis were done in the Soil Physics and Soil Fertiltiy Laboratory of the Federal University of Parana State.

The soil presented the following original chemical and physical attributes: sand $=517 \mathrm{~g} \mathrm{~kg}^{-1}$; silt loam = $158 \mathrm{~g} \mathrm{~kg}^{-1}$; clay $=325 \mathrm{~g} \mathrm{~kg}^{-1}$ (EMBRAPA, 1997); $\mathrm{pH} \mathrm{CaCl}_{2}=3.9 ; \mathrm{Ca}^{2+}=0.3 \mathrm{cmol}_{\mathrm{c}} \mathrm{dm}^{-3} ; \mathrm{Mg}^{2+}$ $=0.2 \mathrm{cmol}_{\mathrm{c}} \mathrm{dm}^{-3} ; \mathrm{K}^{+}=0.12 \mathrm{cmol}_{\mathrm{c}} \mathrm{dm}^{-3} ; \mathrm{Al}^{3+}=1.9$ $\mathrm{cmol}_{\mathrm{c}} \mathrm{dm}^{-3} ; \mathrm{H}+\mathrm{Al}=11.3 \mathrm{cmol}_{\mathrm{c}} \mathrm{dm}^{-3} ; \mathrm{CTC}$ (cation exchange capacity) $=11.9 \mathrm{cmol}_{\mathrm{c}} \mathrm{dm}^{-3} ; \mathrm{V}$ (basis saturation $)=5.2 \% ; P=1.0 \mathrm{mg} \mathrm{dm}^{-3}$ and organic carbon $=23 \mathrm{~g} \mathrm{~kg}^{-1}$ (Pavan et al., 1992).

A biosolid (from sewage sludge) from the Sewage Treatment Station Belem (SANEPAR) was treated and desinfected by the "Advanced alkaline stabilization with accelerated subsequent drying process" (N-Viro Process) and sieved on a $4 \mathrm{~mm}$ sieve. The agronomic characteristics of the alkaline biosolid produced were: moisture $=18 \%, \mathrm{NC}$ (neutralization capacity $=\mathrm{ECaCO}_{3}$ ) = 93,38\%;

\footnotetext{
${ }^{1}$ The results of soil extractable phosphorus, accumulated phosphorus, grain and dry mass production by common bean plants in this same oxisol was recently published, in Portuguese language, according the most adequated formulation for the works extracted from the dissertation of the first author.
} 
DA SILVA L.C. et al. Attributes of acidity and exchangeable...

RCTN (relative capacity of total neutralization) = 67.54\%; $\mathrm{pH}\left(\mathrm{CaCl}_{2} 0.01 \mathrm{~mol} \mathrm{dm}{ }^{-3}\right)=12.8 ; \mathrm{N}=4.9 \mathrm{~g}$ $\mathrm{kg}^{-1} ; \mathrm{P}_{2} \mathrm{O}_{5}=3.47 \mathrm{~g} \mathrm{~kg}^{-1}$ (or $1.51 \mathrm{~g} \mathrm{~kg}^{-1}$ of total $\mathrm{P}$ ); $\mathrm{K}_{2} \mathrm{O}=1.0 \mathrm{~g} \mathrm{~kg}^{-1}$; total $\mathrm{S}=1.0 \mathrm{~g} \mathrm{~kg}^{-1}$; total $\mathrm{Ca}=193$ $\mathrm{g} \mathrm{kg}^{-1}\left(\mathrm{CaO}=269,9 \mathrm{~g} \mathrm{~kg}^{-1}\right)$; total $\mathrm{Mg}=111 \mathrm{~g} \mathrm{~kg}^{-1}$ $\left(\mathrm{MgO}=182,7 \mathrm{~g} \mathrm{~kg}^{-1}\right)$; organic carbon $=31.1 \mathrm{~g} \mathrm{~kg}^{-1}$.

This alkaline biosolid was added by levels of $0.436 \% \mathrm{P}, 0.872 \% \mathrm{P}$ and $1.745 \% \mathrm{P}$ from the partially acidulated rock phosphate Alvorada, single superphosphate and triple superphosphate whose P content and granulometric fractions are shown in the Table 1.

TABLE 1 - Phosphorus concentration and granulometric fraction of partially acidulated rock phosphate Alvorada, single superphosphate, triple superphosphate

\begin{tabular}{|c|c|c|c|c|c|c|c|c|c|c|c|}
\hline \multirow[t]{3}{*}{ SOP $^{1}$} & $\mathrm{TP}^{2}$ & ${ }^{3} \mathrm{TTP}_{2} \mathrm{O}_{5}$ & $\begin{array}{c}{ }^{4} \mathrm{P}_{2} \mathrm{O}_{5} \\
\mathrm{CNA} \\
+ \\
\mathrm{H}_{2} \mathrm{O} \\
\end{array}$ & $\begin{array}{c}{ }^{5} \mathrm{P}_{2} \mathrm{O}_{5} \\
\mathrm{H}_{2} \mathrm{O}\end{array}$ & \multirow[b]{2}{*}{0.08} & \multirow[b]{2}{*}{0.10} & \multicolumn{2}{|r|}{$\begin{array}{l}\text { Mesh } \\
(\mathrm{mm})\end{array}$} & \multirow[b]{2}{*}{1} & \multirow[b]{2}{*}{2} & \multirow[b]{2}{*}{4} \\
\hline & \multirow{2}{*}{\multicolumn{4}{|c|}{---------g kg ${ }^{-1}$}} & & & 0.25 & 0.5 & & & \\
\hline & & & & & \multicolumn{7}{|c|}{$\begin{array}{l}\text { Granulometric fractions } \\
\left.\text { (GF g kg })^{6}\right)^{6}\end{array}$} \\
\hline $\mathrm{PAP}^{7}$ & 84.3 & $193.4^{7}$ & 148.2 & 6.34 & 65.70 & 213.10 & 172.10 & 180.60 & 165.60 & 5.80 & 0.00 \\
\hline $\mathrm{SSP}^{8}$ & 64.2 & $147.4^{7}$ & 128.9 & 9.22 & 0.00 & 0.00 & 0.00 & 0.10 & 103.10 & 876.50 & 20.30 \\
\hline $\mathrm{TSP}^{9}$ & 195.1 & 447 & 441.5 & 40.04 & 0.00 & 0.00 & 0.00 & 0.00 & 2,20 & 846.70 & 150.20 \\
\hline
\end{tabular}

${ }^{1}$ SOP - source of phosphorus added to alkaline biosolid

${ }^{2} \mathrm{TP}$ - total phosphorus concentration in the source, $\mathrm{g} \mathrm{kg}^{-1}$, determined by the method of molibdate blue phosphorus, preceeded by nitroperchloric digestion

${ }^{3} \mathrm{TTP}_{2} \mathrm{O}_{5}$ - total concentration of $\mathrm{P}_{2} \mathrm{O}_{5}$ in the source, $\mathrm{g} \mathrm{kg}$, obtained by calculation based in the total phosphorus concentration

${ }^{4} \mathrm{P}_{2} \mathrm{O}_{5}$ CNA $+\mathrm{H}_{2} \mathrm{O}$ - total concentration of $\mathrm{P}_{2} \mathrm{O}_{5}$ in the soluble source, $\mathrm{g} \mathrm{kg}^{-1}$, by the method of Amonium neutrum citrate + water

${ }^{5} \mathrm{P}_{2} \mathrm{O}_{5} \mathrm{H}_{2} \mathrm{O}$ - soluble phosphorus concentration in water, in $\mathrm{g} \mathrm{kg}^{-1}$

${ }^{6} \mathrm{GF} \mathrm{g} \mathrm{kg}{ }^{-1}$ - quantity of the granulometric fraction retained in the mesh, $\mathrm{g} \mathrm{kg}^{-1}$

${ }^{7}$ PAP - Partially acidulated rock phosphate Alvorada

${ }^{8}$ SSP: Single superphosphate

${ }^{9} \mathrm{TSP}$ - Triple superphosphate

To establish the treatments (levels of phosphorus added) was used an unique test dose of $45.85 \mathrm{~kg} \mathrm{ha}^{-1}$ of $\mathrm{P}\left(105 \mathrm{~kg} \mathrm{ha}^{-1}\right.$ of $\mathrm{P}_{2} \mathrm{O}_{5}$ or $23 \mathrm{mg} \mathrm{dm}^{-}$ ${ }^{3}$ of $P$ ) from the level of $0.436 \% P, 0.872 \% P$ and $1.745 \% \mathrm{P}$ according to CQFS-SC/RS (2004). A maximum dose of $10500 \mathrm{~kg} \mathrm{ha}^{-1}$ dry weight of the mixture $P$ source + sewage alkaline biosolid was obtained when was recommended the test dose from the level of $0.436 \% \mathrm{P}$ for all sources. Based on this test dose was taken $10500 \mathrm{~kg} \mathrm{ha}^{-1}$ of pure sewage alkaline biosolid as specific controls generating the level of $0 \% \mathrm{P}$ for each source of $\mathrm{P}$ added (treatments 1, 5 and 9 on the Table 2).

Four levels and three phosphorus sources originated 12 treatments with 4 replications. Thus, the unique causes of variation were level and source of $\mathrm{P}$ added. The mixtures of alkaline biosolid + sources of $P$ to supply $45.85 \mathrm{~kg} \mathrm{P} \mathrm{ha}^{-1}$, calculated for 1.0 ha (ha) and the quantities of pure alkaline biosolid on the controls were calculated for vases of $3 \mathrm{dm}^{3}$ containing $2.5 \mathrm{~kg}$ of soil dry weight (Table 2).

Following, the quantities of alkaline biosolid and sources of $P$ were weighted on a precision balance and manual and homogeneously mixed in plastic bags with $6 \mathrm{~cm} \times 12 \mathrm{~cm}$ was manually and homogeneously shaked for four times for each treatment.

The treatments were applied and mixed to the soil which was watered till its water retention capacity. Six plants of the IPR Uirapuru variety of common bean were cultivated per vase, under the soil water retention capacity during all the plant cicle.

The nitrogen and potassium fertilization were recommended to 1.0 ha (CQFS-SC/RS, 2004) and calculated for vases and added to the soil surface of vases at the 13 day after seed germination.

\footnotetext{
${ }^{2}$ Latossolo Vermelho Distrófico típico according EMBRAPA (1999), collected on a Perennial subtropical forest under secondary sucession and never cultivated. Parana State Sanitation Company.

For more details about the methodology see the dissertation of the first author, defended in the Post-graduating program in Soil Science of the Federal University of Parana State, Brazil.

In English language understand "phosphating" or, simply, "phosphate". In protuguese language understand "fosfatagem".
} 
DA SILVA L.C. et al. Attributes of acidity and exchangeable...

TABLE 2 - Total doses, per vase, of alkaline biosolid added by phosphorus, amount of phosphorus sources and pure biosolid in the mixture for treatment establishment

\begin{tabular}{|c|c|c|c|c|c|c|}
\hline \multirow{3}{*}{$\begin{array}{l}\text { Treatment } \\
\text { (T) }\end{array}$} & \multirow{3}{*}{ SPA $^{1}$} & \multirow{3}{*}{$\begin{array}{c}\text { LPA }^{2} \\
(\%)\end{array}$} & $\mathrm{TD}^{3}$ & $\mathrm{SQ}^{4}$ & QOS $^{5}$ & \multirow[t]{2}{*}{$\mathrm{DP}^{6}$} \\
\hline & & & & & & \\
\hline & & & \multicolumn{4}{|c|}{ - } \\
\hline $\mathrm{T} 1$ & $\mathrm{FPA}^{7}$ & 0.000 & 13.125 & 13.125 & 0.000 & 0.000 \\
\hline $\mathrm{T} 2$ & FPA & 0.436 & 13.125 & 12.445 & 0.680 & 0.057 \\
\hline T3 & FPA & 0.872 & 6.563 & 5.883 & 0.680 & 0.057 \\
\hline $\mathrm{T} 4$ & FPA & 1.745 & 3.281 & 2.612 & 0.680 & 0.057 \\
\hline T5 & $\mathrm{SSP}^{8}$ & 0.000 & 13.125 & 13.125 & 0.000 & 0.000 \\
\hline T6 & SSP & 0.436 & 13.125 & 12.235 & 0.890 & 0.057 \\
\hline $\mathrm{T} 7$ & SSP & 0.872 & 6.563 & 5.673 & 0.890 & 0.057 \\
\hline T8 & SSP & 1.745 & 3.281 & 2.391 & 0.890 & 0.057 \\
\hline T9 & $\mathrm{TSP}^{9}$ & 0.000 & 13.125 & 13.125 & 0.000 & 0.000 \\
\hline T10 & TSP & 0.436 & 13.125 & 12.831 & 0.294 & 0.057 \\
\hline $\mathrm{T} 11$ & TSP & 0.872 & 6.563 & 6.269 & 0.294 & 0.057 \\
\hline T12 & TSP & 1.745 & 3.281 & 2.987 & 0.294 & 0.057 \\
\hline
\end{tabular}

${ }^{1}$ SPA: source of phosphorus addition to the alkaline sewage biosolid

${ }^{2}$ LPA: level of phosphorus addition to alkaline sewage bosolid

${ }^{3} \mathrm{TD}$ : total dose per pot of alkaline sewage biosolid

${ }^{4} \mathrm{SQ}$ : quantity of pure alkaline sewage biosolid in the mixture of phosphorus added

${ }^{5}$ QOS: quantity of phosphorus source in the mixture of addition to supply the test dose of $45.85 \mathrm{~kg} \mathrm{P}$

${ }^{6} \mathrm{DP}$ : dose of phosphorus recommended by $1.0 \mathrm{ha}^{-1}$ (2000000 mean $\mathrm{kg}$ of the arable layer of soil), equivalent to

$105 \mathrm{~kg} \mathrm{ha}^{-1}$ of $\mathrm{P}_{2} \mathrm{O}_{5}$ considered a soil density $=1.000 \mathrm{~g} \mathrm{~cm}^{-3}$ )

${ }^{7} \mathrm{PAP}$ : partially acidulated rock phosphate Alvorada

${ }^{8}$ SSP: single superphosphate

${ }^{9}$ TSP: triple superphosphate

After harvest (95 days after sowing) was collected compound soil samples (from six single samples) to the following analysis: $\mathrm{pH}\left(\mathrm{CaCl}_{2} 0.01\right.$ mol $\left.\mathrm{dm}^{-3}\right)$, aluminum $\left(\mathrm{Al}^{3+}\right)$ and potential acidity $(\mathrm{H}+$ $\mathrm{Al})$ and soil exchangeable calcium $\left(\mathrm{Ca}^{2+}\right)$ and magnesium $\left(\mathrm{Mg}^{2+}\right)$ in the Soil Chemistry and Fertility Laboratory of the Federal University of Parana State.

The experiment was conducted in a completely randomized design 4 by 3 . The homogeneity of variance was verified by the Bartlett's test and the means comparison was carried out by the Tukey's test $(P<0.05)$ in the software Mstatc (Michigan State University). Adjustment curves were generated to verify correlations between soil acidity variables, exchangeable calcium and treatments. There were not data transformations.

\section{RESULTS AND DISCUSSION}

The analysis of variance of soil acidity attributes and exchangeable calcium and magnesium are founded in the Table 3 .

All the treatments increased the mean values of soil $\mathrm{pH}$ for a high significant and isolated interaction between level and source of $P$ added $(F<0.01$ in the Table 3$)$. The low levels of $P$ added $(0 \% \mathrm{P}=$ specific controls and $0.436 \% \mathrm{P})$ were responsible by the larger effects and occasioned increasings of up to 0.5 unit in relation to the original soil $\mathrm{pH}$.

1.0 hectare (ha): $2 \times 10^{6} \mathrm{~kg}$ average of soil from the soil arable layer. The analysis of soil density showed $1.060 \mathrm{~g} \mathrm{~cm}^{-3}$ which was assumed to be $1.000 \mathrm{~g} \mathrm{~cm}^{-3}$ for purpose of phosphate fertilizer recommendation from the treatments. 
DA SILVA L.C. et al. Attributes of acidity and exchangeable...

TABLE 3 - Analysis of variance of acidity variables and soil exchangeable calcium and magnesium

\begin{tabular}{|c|c|c|c|c|c|c|}
\hline \multirow[b]{2}{*}{$\begin{array}{l}\text { Source of } \\
\text { variation }\end{array}$} & \multirow[b]{2}{*}{ DF } & \multirow[b]{2}{*}{$\mathrm{pH} \mathrm{CaCl} 2$} & $\mathrm{H}+\mathrm{Al}$ & $\mathrm{Al}$ & $\mathrm{Ca}^{2+}$ & $\mathrm{Mg}^{2+}$ \\
\hline & & & \multicolumn{4}{|c|}{ - } \\
\hline L & 3 & $0.941 * *$ & $16.941 * *$ & 4.052 ** & 6,356 ** & 2.574 ** \\
\hline S & 2 & $0.056 * *$ & 0.806 * & 0.126 ** & 1.802 ** & 1.681 ** \\
\hline$L \times S$ & 6 & $0.016^{n s}$ & $0.558^{n s}$ & $0.025^{n s}$ & $0.387^{* *}$ & 0.266 ** \\
\hline Error & 36 & 0.009 & 0.239 & 0.012 & 0.017 & 0.046 \\
\hline$x^{2}$ & & $8.03^{\mathrm{ns}}$ & $13.938^{n s}$ & $9.922^{n s}$ & $18.59^{\mathrm{ns}}$ & $14.044^{\mathrm{ns}}$ \\
\hline${ }^{5} \mathrm{CV}(\%)$ & & 2.19 & 7.05 & 12.76 & 8.64 & 16.49 \\
\hline DMS & & 0.161 & 0.831 & 0.186 & 0.221 & 0.364 \\
\hline
\end{tabular}

$* *$ : Very significant at level of $99 \%$ of probability

*: Significant at level of $95 \%$ of probability

ns: non-significant at level of $95 \%$ of probability

DF: degrees of freedom

$\mathrm{L}$ : level of phosphorus added to sewage alkaline biosolid

S: source of phosphorus added to sewage alkaline biosolid

$L \times S$ : interaction between factors level and source of phosphorus added to sewage alkaline biosolid

$\mathrm{X}^{2}$ : qui-square of the Bartlett's test

CV (\%): coefficient of variation, in percentage

DMS: minimum significant difference by the Tukey's Test $(P<0.05)$

The level $0.436 \% \mathrm{P}$ exerted the larger effect in the soil $\mathrm{pH}$. This fact may be ratified by the results of Da Silva et al. (2010) who used the same methodology of this study and obtained an increasing for soil $\mathrm{pH}$ according the decreasing in the levels of $P$ added. It should be noted that these treatments have a lesser quantity of pure alkaline biosolid compared to the specific controls (Table 2), which were composed only by pure alkaline biosolid. Thus, the equivalent increase expected in soil $\mathrm{pH}$ caused by the level of $0.436 \% \mathrm{P}$ compared to those obtained for the control $(0 \% \mathrm{P})$ was ratified.

The Figure 1 shows the linearity between soil $\mathrm{pH}$ increasing according to the decreasing in the levels of $\mathrm{P}$ added. This fact may be due to the soil acidity corrective potential of the pure alkaline biosolid present in the mixture related to the treatment $0.436 \%$ P. According Oliveira et al. (2002) this fact occurs due to the soil alkaline reaction of the materials used in the treatment process of sewage biosolids $\left(\mathrm{CaCO}_{3}\right.$ and $\left.\mathrm{CaO}, \mathrm{Ca}(\mathrm{OH})\right)$. The works developed by Melo e Marques (2000), Silva et al. (1998) and Christie et al. (2001) used increasing doses of sewage sludge alone and also are according to the present results.

The sources of $\mathrm{P}$ added differ in relation to its chemical composition, solubility and accompanying cation. The PAP was statistically equal to the
TSP in relation to the soil $\mathrm{pH}$. The PAP increased contact with the ground due to its size mash corroborate with the solubilization of components from the non-acidulated portion of this source. Among the components dissolved is the carbonate anion which reacted with the $\mathrm{H}^{+}$in the soil solution and caused the increases in the soil $\mathrm{pH}$ values verified (Novais e Smith, 1999; Osztoics et al. 2005). The literature, generally, shows that the TSP decreases the solution $\mathrm{pH}$ value around the granule of this $\mathrm{P}$ source. More works should be developed to study the effects of this $\mathrm{P}$ source above soil $\mathrm{pH}$. A different result was encountered by Beltrán et al. (1998) who applied equal $P$ doses from different sources to the soil and observed superiority for a reactive phosphate rock in comparison to another traditional $P$ sources, among them, the TSP.

All the treatments decreased the $\mathrm{Al}^{3+}$ concentration in relation to the initial soil value for an isolated interaction between level and source of $P$ added $(\mathrm{F}<0.01$ in the Table 3$)$. The Figure 2 shows linear increasings for soil $\mathrm{Al}^{3+}$ concentration according to the levels of $\mathrm{P}$ added. Similarly, the results verified for soil $\mathrm{pH}$, the levels of $0 \% \mathrm{P}$ e $0.436 \% \mathrm{P}$ generate the larger reductions, and it was verified values of up to $1.5 \mathrm{cmol}_{\mathrm{c}} \mathrm{dm}^{-3}$ lesser in the soil. 
DA SILVA L.C. et al. Attributes of acidity and exchangeable...

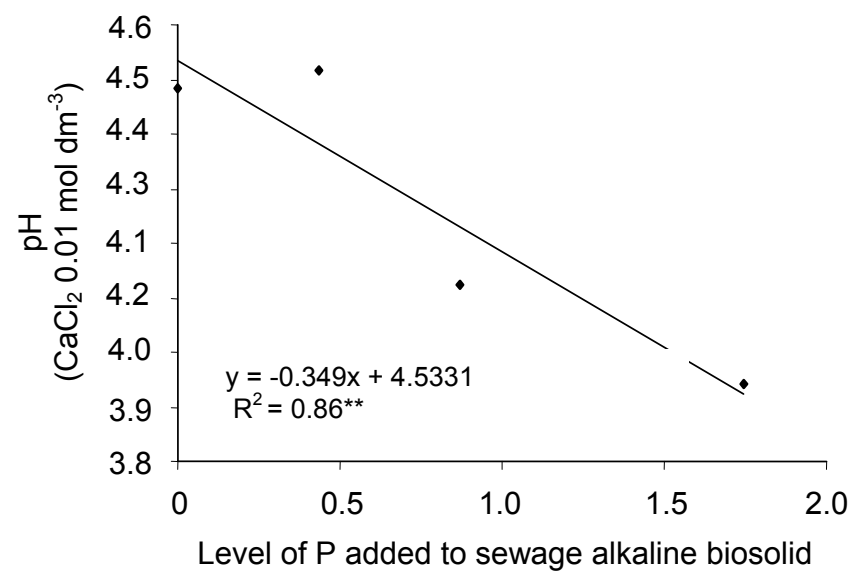

(\%)

FIGURE 1 - Tendency curve of mean soil $\mathrm{pH}$ according the level of $\mathrm{P}$ added to sewage alkaline biosolid from three sources (**: significant at the level of $99 \%$ probability by the F Test)

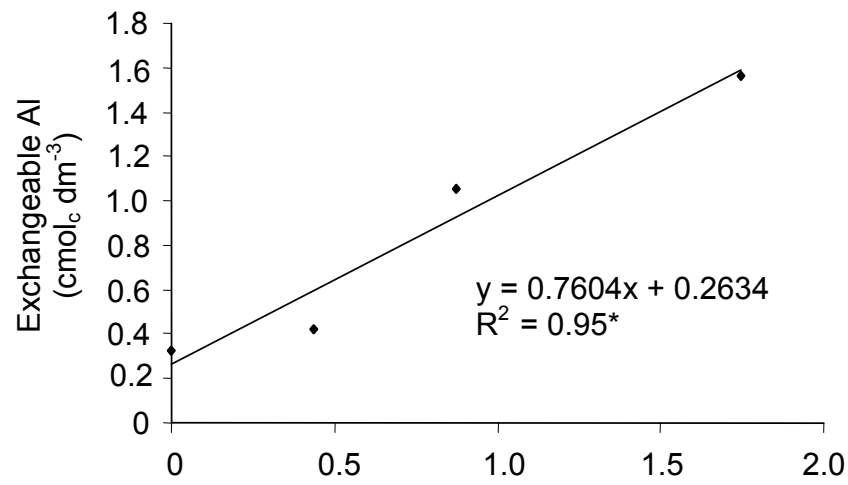

Level of $\mathrm{P}$ added to sewage alkaline biosolid

$(\%)$

FIGURE 2 - Tendence curve of mean soil exchangeable aluminum according the level of $P$ added to sewage alkaline biosolid from the three sources ( ${ }^{*}$ : significant at the level of $95 \%$ probability by the $\mathrm{F}$ Test)

This observation also must be related to the increasing quantities of the pure alkaline biosolid in the mixtures which increased the soil $\mathrm{pH}$ values and, as a consequence, decreased the soil $\mathrm{Al}^{3+}$ concentration. This results are the same verified in the work carried out by Da Silva (2010) who obtained increases in the soil $\mathrm{pH}$ values with consequent decreases in the $\mathrm{Al}^{3+}$ values according to the decreasing in the levels of $\mathrm{P}$ added. his fact shows the inverse proportionality between this acidity variables which was ratified by the Figure 3 and the works developed by Sloan e Basta (1995) and Fia et al. (2005) that used increasing doses of sewage sludge also in acidic soils.

All the sources of $P$ added also contributed to the decreasing of the exchangeable $\mathrm{Al}^{3+}$ concentration in the soil. This fact may be due, partially, to the $\mathrm{Al}^{3+}$ precipitation with the soluble $\mathrm{P}$ present in these P sources (Novais e Smith, 1999). Therefore, numerically, the lesser concentration of exchangeable $\mathrm{Al}^{3+}$ was verified for partially acidulated rock phosphate Alvorada (Table 4), which occasioned the larger decrease in relation to the original value. This result, probably, is due to the increase in the soil $\mathrm{pH}$ and, consequently, in the values of soil exchangeable $\mathrm{Al}$, that is a well known fact verified in the relevant literature. Da Silva et al. (2010) developed a work using the same methodology and his results confirm those obtained in the present work. Also according to the works developed by Beltrán et al. (1998) and Osztoics et al. (2005) this fact is related to the larger reactivity of the phosphorite present in its non-acidulated portion which, added to the liming potential of the alkaline biosolid present in the mixtures, corroborated to the increasing verified for soil $\mathrm{pH}$ with concomitantly decrease in the soil $\mathrm{Al}^{3+}$ concentration. 
DA SILVA L.C. et al. Attributes of acidity and exchangeable...

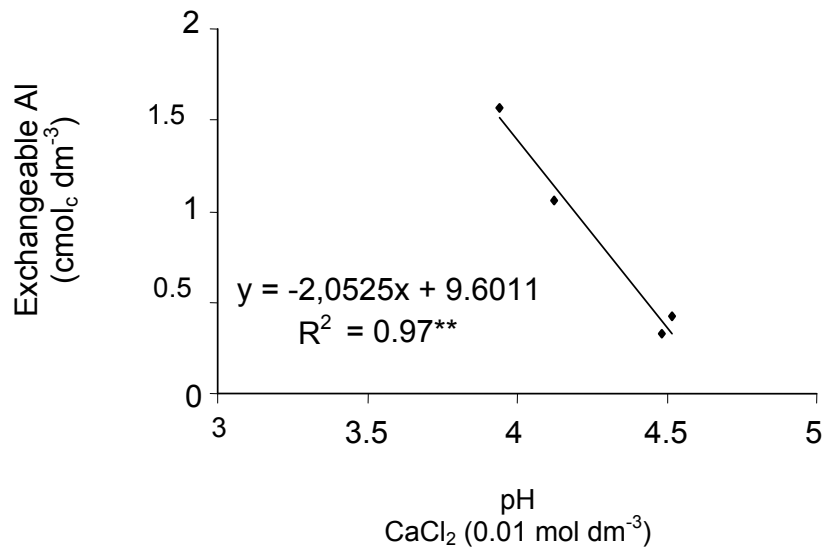

FIGURE 3 - Tendence curve of mean soil exchangeable aluminum according the mean soil pH (**: significant at the level of $99 \%$ probability by the $\mathrm{F}$ Test)

TABLE 4 - Mean comparison of $\mathrm{pH} \mathrm{CaCl}_{2}$, exchangeable aluminum and potential acidity $(\mathrm{H}+\mathrm{Al})$ on an oxisol for sources of phosphorus added to sewage alkaline biosolid.

\begin{tabular}{|c|c|c|c|}
\hline \multirow{3}{*}{ Source $^{1}$} & \multicolumn{3}{|c|}{ Mean } \\
\hline & \multirow{2}{*}{$\mathrm{pH} \mathrm{CaCl}{ }_{2}$} & $\mathrm{Al}^{3+}$ & $\mathrm{H}+\mathrm{Al}$ \\
\hline & & \multicolumn{2}{|c|}{-----(cmol $\left.\mathrm{dm}^{3}\right)^{-------}$} \\
\hline $\mathrm{PAP}^{2}$ & $4.312 \mathrm{a}$ & $0.744 \mathrm{a}$ & 6.669 a \\
\hline $\mathrm{SSP}^{3}$ & $4.200 \mathrm{~b}$ & $0.913 b$ & $7.075 \mathrm{a}$ \\
\hline $\mathrm{TSP}^{4}$ & $4.287 \mathrm{a}$ & $0.875 b$ & $7.037 \mathrm{a}$ \\
\hline
\end{tabular}

Note: Means followed by the same word at the vertical not differ statistically by the Tukey's Test the level of probability of $95 \%$

${ }^{1}$ Source - source of phosphorus added to sewage alkaline biosolid

${ }^{2} \mathrm{PAP}$ - partialy acidulated rock phosphate Alvorada

${ }^{3}$ SSP - single superphosphate

${ }^{4} \mathrm{TSP}$ - triple superphosphate

Similarly to the results verified for soil $\mathrm{pH}$ and $\mathrm{Al}^{3+}$ the significant and isolated interaction between level $(F<0.01)$ and source $(F<0.05)$ of $P$ added (Table 3 ) shows that all the treatments, included specific controls $(0 \% \mathrm{P})$, decrease the soil potential acidity in relation to the initial value.

In the Figure 4 is observed that the controls and the level of $0.436 \% \mathrm{P}$ exert the larger effects and occasioned a linear decrease in soil potential acidity values (values of up to $5.3 \mathrm{cmol}_{\mathrm{c}} \mathrm{dm}^{-3}$ ). These increasings were verified to the extent that increased the levels of $P$ added. Therefore, it's not happened according to the presence of larger quantities of soluble $P$, but, due to the decrease in the quantities of sewage alkaline biosolid present in the mixtures of $P$ added (Table 2). This result was also observed by Da Silva et al. (2010) who used similar methodology to this work. Another works as those developed by Sloan e Basta (1995), Silva et al. (1998), Melo e Marques (2000), Fia et al. (2005) and Christie et al. (2001) confirm the effects observed in the present work for soil $\mathrm{pH}$ and, conseScientia Agraria, Curitiba, v.12, n.1, p.041-051, Jan/Feb. 2011 quently, for the values of soil exchangeable $\mathrm{Al}$ and potential acidity.

The sources of $P$ added show equivalent effects among each other about the soil potential acidity (Table 4 ) in relation to the initial soil value. Phosphorus sources as partially acidulated rock phosphate Alvorada can contributes with the increase in the soil $\mathrm{pH}$ and, consequently, with the decrease of soil $\mathrm{Al}^{3+}$ concentration. Additionally, the exchangeable $\mathrm{Al}$ can precipitate with the soluble $\mathrm{P}$ present in sources as SSP and TSP (Novais \& Smith, 1999).

These effects added to those exerted by the larger quantities of pure alkaline biosolid present in the level of $0.436 \% \mathrm{P}$ may have corroborated with the linear decrease for soil potential acidity according the increase of the soil pH (Figure 5), and also with the decreasing in the soil potential acidity according the decreasing in the soil exchangeable Al (Figure 6). These results are very similar to those encountered in the work developed by Guedes et al. (2006) who also used increasing doses of sewage 
DA SILVA L.C. et al. Attributes of acidity and exchangeable...

biosolids and Da Silva et al. (2010), Osztoics et al.

(2005) and Beltrán et al. (1998).

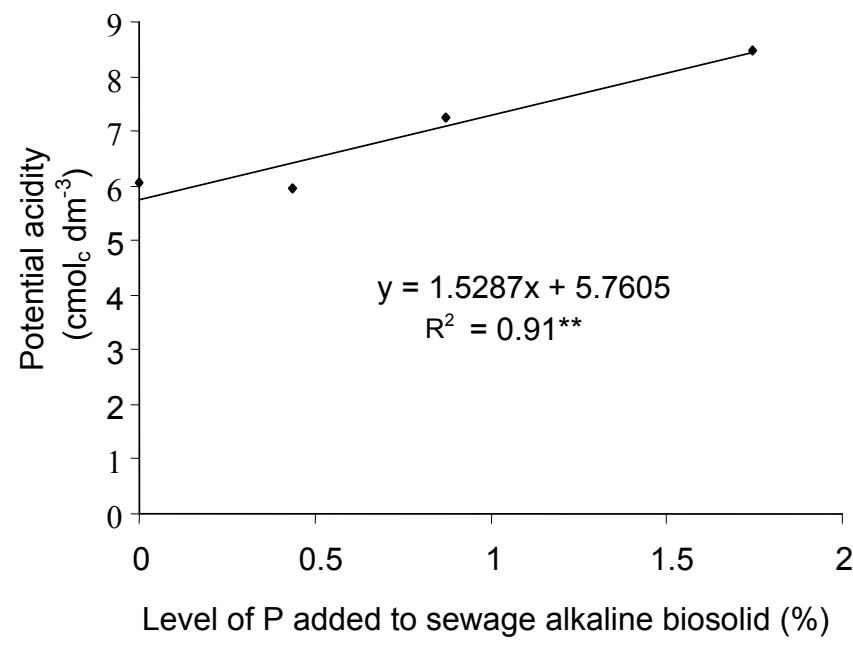

FIGURE 4 - Tendence curve of mean soil potential acidity according the level of $\mathrm{P}$ added to sewage alkaline biosolid from the three sources (**: significant at the level of $99 \%$ probability by the $\mathrm{F}$ Test)

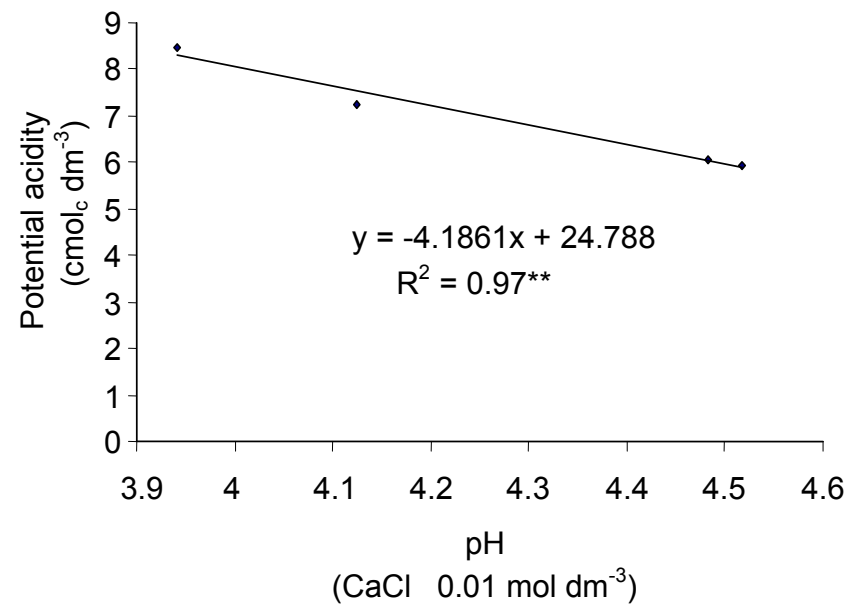

FIGURE 5 - Tendence curve of mean soil potential acidity according the mean soil pH (**: significant at the level of $99 \%$ probability by the $\mathrm{F}$ Test)

The treatments also increased the soil $\mathrm{Ca}^{2+}$ in comparison to the initial soil value for a significant interaction between level and source of $\mathrm{P}$ added $(\mathrm{F}<0.01)$ as shown in the Table 3 . The Figure 7 shows the linearity of the correlation verified between level of $\mathrm{P}$ added and soil $\mathrm{Ca}^{2+}$ for all sources investigated for $\mathrm{P}$ added.

The larger soil exchangeable $\mathrm{Ca}$ concentrations were $2.9 \mathrm{cmol}_{\mathrm{c}} \mathrm{dm}^{-3}$ and $2.2 \mathrm{cmol}_{\mathrm{c}} \mathrm{dm}^{-3}$ obtained, respectively, for the levels $0 \% \mathrm{P}$ and $0.436 \% \mathrm{P}$ from the partially acidulated rock phosphate Alvorada. The larger dissolution of those reac- tive rock phosphate due to the initial soil acidic condition (Novais e Smith, 1999; Korndörfer et al., 1999) added to the decrease in the soil acidity occasioned by the alkaline biosolid may have corroborated to these results observed for partially acidulated rock phosphate Alvorada in relation to the soil exchangeable $\mathrm{Ca}$ from the level of $0.436 \%$. It should be emphasised that this treatment occasioned an equivalent $\mathrm{Ca}^{2+}$ concentration with the specific control $(0 \% \mathrm{P})$ which was composed by only pure alkaline biosolid. 
DA SILVA L.C. et al. Attributes of acidity and exchangeable...

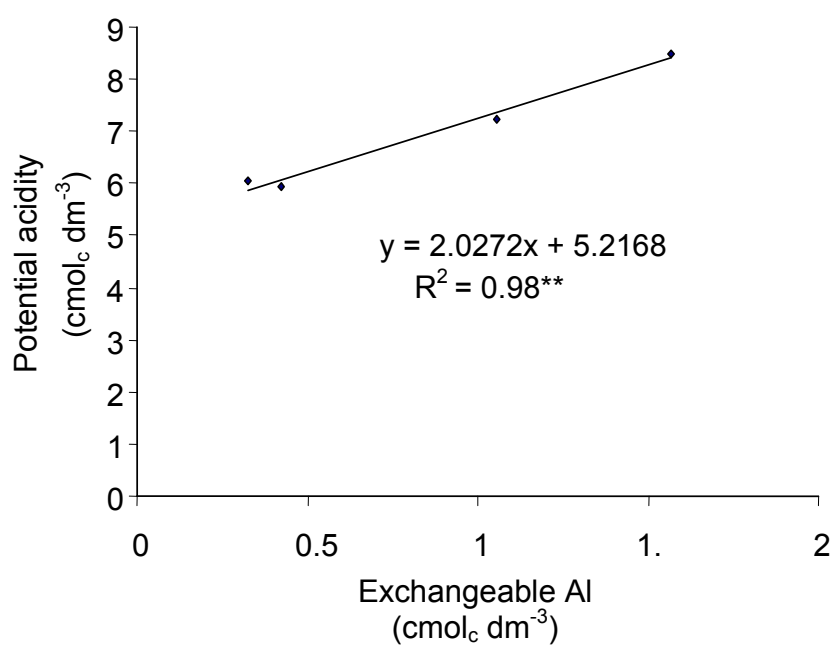

FIGURE 6 - Tendence curve of mean soil potential acidity according the mean soil exchangeable aluminum (**: significant at the level of $99 \%$ probability by the $\mathrm{F}$ Test)

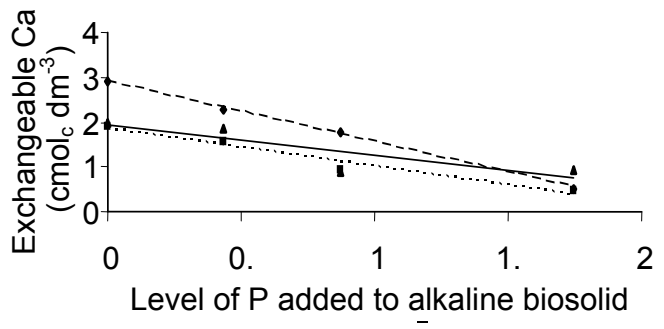

$(\%)$

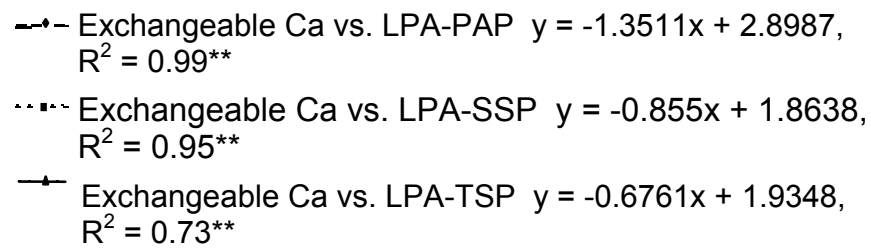

FIGURE 7 - Tendence curve of soil exchangeable calcium according the level of $P$ added to sewage alkaline biosolid from the partially acidulated rock phosphate Alvorada (LPA-PAP), single superphosphate (LPA-SSP) and triple superphosphate (LPA-TSP) $\left({ }^{* *}\right.$ : significant at the level of $99 \%$ probability by the F Test)

These results may be attributed to the high total Ca concentration $\left(193 \mathrm{~g} \mathrm{~kg}^{-1}\right.$ ) present in the larger doses of the alkaline biosolid in these treatments (Logan \& Harrison, 1995). Additionally, may be due to the high content of total Ca present also in the sources of $\mathrm{P}$ added (CQFS-SC/RS, 2004 and Novais e Smith, 1999). The same considerations were made in the discussions held by Da Silva et al. (2010) who used an identical methodology using another oxisol.

All the treatments increase the soil exchangeable $\mathrm{Mg}^{2+}$ concentration in relation to the original value for a significant interaction between level and source of $P$ added $(F<0.01)$. Therefore, the larger values of $\mathrm{Mg}^{2+}$ were verified also for the treatments refered to the low levels of $\mathrm{P}$ added $(0 \%$ e $0.436 \% \mathrm{P}$ ) from the three sources used, despite of low correlation verified for $\mathrm{Mg}^{2+}$ according the level of $\mathrm{P}$ added from the partially acidulated rock phosphate Alvorada (Figure 8). On the contrary, was observed a high correlation between $\mathrm{Mg}^{2+}$ and treatments from the sources SSP and TSP.

These results may be due to the larger total $\mathrm{Mg}$ concentration present in the doses of pure alkaline biosolid in the low levels of $P$ added (Logan $e$ Harrison, 1995) beyond the small quantity of total $\mathrm{Mg}$ in the source SSP (CQFS-SC/RS, 2004) which occasioned an increasing of up to $2.1 \mathrm{cmol}_{\mathrm{c}} \mathrm{dm}^{-3}$ in the soil exchangeable $\mathrm{Mg}$ from the level $0.436 \% \mathrm{P}$.

An identical work was developed by $\mathrm{Da}$ Silva et al. (2010) in which the exchangeable Mg concentration of another acidic oxisol was evaluated. These authors show that this variable increase concomitantly decreasing of the levels of $\mathrm{P}$ added to the alkaline biosolid. Another authors in the relevant literature applied increasing doses of sewage sludge 
DA SILVA L.C. et al. Attributes of acidity and exchangeable...

in the soil and evaluated the soil $\mathrm{Mg}^{2+}$ concentration according the doses applied. Similar result for values of soil $\mathrm{Mg}^{2+}$ concentrations were founded by Venâncio Gomes et al. (2005) and increases in the concentration of $\mathrm{Mg}^{2+}$ according the increasing of alkaline biosolid doses (Simonete et al., 2003). Also when Silva et al. (1995) and Silva et al. (2001) applied alkaline biosolids in the presence or not of mineral phosphatic fertilizers they verified a significant participation of $\mathrm{Mg}^{2+}$ and in the sum of bases and saturation of soil bases.

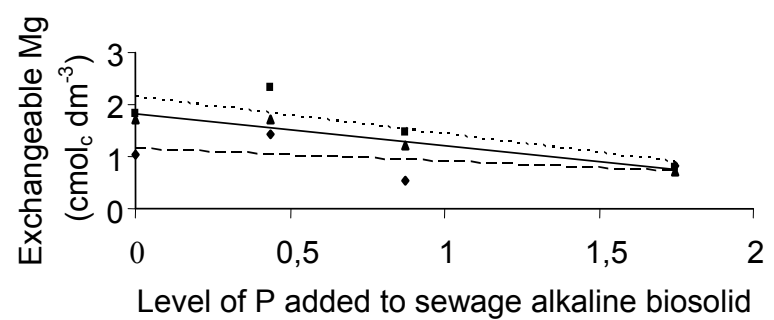

(\%)

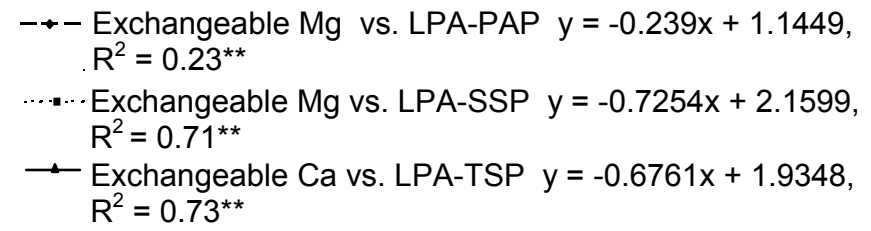

FIGURE 8 - Tendency curve of soil exchangeable magnesium according the level of $P$ added to sewage alkaline biosolid from the partially acidulated rock phosphate Alvorada (LPA-PAP), single superphosphate (LPA-SSP) and triple superphosphate (LPA-TSP) $\left({ }^{* *}\right.$ : significant at the level of $99 \%$ probability by the F Test)

\section{CONCLUSIONS}

Under the present experimental conditions phosphate alkaline biosolid applied in acidic Oxisol: 1. Increases its $\mathrm{pH}\left(\mathrm{CaCl}_{2} 0.01 \mathrm{~mol} \mathrm{dm}^{-3}\right)$ and exchangeable calcium and magnesium and decreases its exchangeable aluminum concentration and potential acidity;

2. Provided the largest increases of soil $\mathrm{pH}$, exchangeable calcium and magnesium and decreases in exchangeable aluminum and potential acidity with the level of $0.436 \% \mathrm{P}$ from the partially acidulated rock phosphate Alvorada and single superphosphate.

\section{AKNOWLEDGEMENTS}

To the Federal University of Parana State: by the opportunity of available learnt and; To the Capes: by the concession of the scholarship.

\section{REFERENCES}

1. BELTRÁN, R. R., SILVEIRA, R. I.; PASSOS, M. J. Disponibilidade de fósforo para plantas de arroz avaliada por extratores químicos. Scientia Agricola, v. 55, n.2, p.233-241, 1998.

2. CHRISTIE, P.; EASSON, D. L.; PICTON, J. R. AND LOVE, S. C. P. Agronomic value of alkaline-stabilized sewage biosolids for spring barley. Agronomy Journal, v.93, n.1, p.144-151, 2001.

3. CQFS - SC/RS - Comissão de Química e Fertilidade do Solo, Sociedade Brasileira de Ciência do Solo, Núcleo Regional Sul, 2004

4. DA SILVA, L. C.; LUCCHESI, L. A. C.; KOEHLER, H. S. Acidity variables and exchangeable calcium and magnesium on an oxisol treated with phosphate alkaline biosolid. Scientia Agraria, v.11, n.4, p.331-342, 2010a.

5. DA SILVA, L. C.; LUCCHESI, L. A. C.; KOEHLER, H. S. Lodo de esgoto alcalinizado adicionado de fósforo aplicado num Latossolo Vermelho Distrófico de Arapoti-PR. Scientia Agraria, v.11, n.5, p.393-405, 2010b.

6. FIA, R.; MATOS, A. T.; AGUIRRE, C. I. Características químicas de solo adubado com doses crescentes de lodo de esgoto caleado. Engenharia na Agricultura, v.13, n.4, p.287-299, 2005.

7. GUEDES, M. C.; ANDRADE, C. A.; POGGIANI, F.; MATTIAZZO, M. E. Propriedades químicas do solo e nutrição do eucalipto em função da aplicação de lodo de esgoto. Revista Brasileira de Ciência do Solo, v.30, n.30, p.267-280, 2006.

8. KORNDÖRFER, G. H.; LARA-CABEZAS, W. A.; HOROWITZ, N. Eficiência agronômica de fosfatos naturais reativos na cultura do milho; Scientia Agricola, v.56, n.2, p.391-396, 1999

9. LOGAN, T. J.; HARRISON, B. J. Physical characteristics of alkaline stabilized sewage sludge (N-Viro Soil) and their effects on soil physical properties. Journal of Environmental Quality, v.24, n.1, p.153-164, 1995

10. MELO, W. J.; MARQUES, M. O. Potencial do lodo de esgoto como fonte de nutrientes para as plantas. In: BETTIOL, W. e CAMARGO, O. A., eds. Impacto ambiental do uso agrícola do lodo de esgoto. EMBRAPA MEIO AMBIENTE, p.109$141,2000$.

11. NOVAIS, R. F.; SMITH, T. J. Fósforo em solo e planta em condições tropicais. Viçosa: UFV, 1999. 399 p.

12. OLIVEIRA, F. C. et al. Efeitos de aplicações sucessivas de lodo de esgoto em um Latossolo Amarelo Distrófico cultivado com cana-de-açucar: Carbono orgânico, condutividade elétrica, pH e CTC. Revista Brasileira de Ciência do Solo, v.26, n.2, p.505-519, 2002

13. OSZTOICS, C.; NÉMETH, B.; MAGYAR, M. Influence of phosphate fertilizer sources and soil properties on trace element 
DA SILVA L.C. et al. Attributes of acidity and exchangeable...

concentrations of red clover. Communications in Soil Science and Plant Analysis, v.36, n.4-6, p.557-57, 2005.

14. SILVA, F. C., BOARETTO, A. E., BERTON, R. S. Efeito de lodo de esgoto na fertilidade de um argissolo vermelhoamarelo cultivado com cana de açúcar. Pesquisa Agropecuária Brasileira, v.36, n.5, p.831-840, 2001.

15. SILVA, F. C.; BOARETTO, A. E.; BERTON, R. S.; ZOTELLI, H. B.; PEIXE, C. A.; MENDONÇA, E. Cana-de-açúcar cultivada em solo adubado com lodo de esgoto: nutrientes, metais pesados e produtividade. Pesquisa Agropecuária Brasileira, v.33, n.1, p.1-8, 1998

16. SILVA, F. C.; BOARETTO, A. E.; BERTON, R. S. Características agrotecnológicas, teores de nutrientes e de metais pesados em cana-de-açúcar (soqueira), cultivada em solo adubado com o lodo de esgoto. In: CONGRESSO BRASILEIRO DE CIÊNCIA DO SOLO, 25., Viçosa. Anais...Viçosa: SBCS/UFV, p.2279-2287, 1995.

17. SIMONETE, M. A.; KIEHL, J. C.; ANDRADE, C. A.; ALMEIDA TEIXEIRA, C. F. Efeito do lodo de esgoto em um Argissolo e no crescimento e nutrição de milho. Pesquisa Agropecuária Brasileira, v.38, n.10, p.1187-1195, 2003.

18. SLOAN, J. J.; BASTA, N. T. Remediation of acid soils by using alkaline biosolids. Journal of Environmental Quality. v.24, n.6, p.1097-1103. 1995.

19. VENÂNCIO GOMES; S. B.; NASCIMENTO, C. W. A; BIONDI, C. M.; ACCIOLY, A. M. A. Alterações químicas em argissolo tratado com lodo de esgoto, Caatinga, v.18, n.3, p.185-194, 2005.

20. VIEIRA, R. F.; TANAKA, R. T.; TSAI, S. M.; PÉREZ, D. V.; SILVA, C. M. M. S. Disponibilidade de nutrientes no solo, qualidade de grãos e produtividade da soja em solo adubado com lodo de esgoto; Pesquisa Agropecuária Brasileira, v.40, n.9, p.919-926, 2005.

Recebido em 16/09/2010

Aceito em 29/03/2011 